Dolly's death leaves researchers woolly on clone ageing issue

Jim Giles and Jonathan Knight

The fate of Dolly the sheep is now certain: with the post mortem complete, her body will be stuffed and put on display at the Museum of Scotland in Edinburgh, UK. But her death has drawn attention to how little is known about the health problems that other clones may or may not suffer.

Dolly was put down on 14 February, suffering from a virus that caused a tumour in her lung. Ian Wilmut, leader of the team that created Dolly at the Roslin Institute near Edinburgh, says that the post mortem revealed no other gross abnormality, apart from her arthritis, which was diagnosed last year.

Dolly, born six years ago, was the first mammal to be cloned, but since then six other mammalian species - cow, mouse, pig, rabbit, goat and domestic cat — have also been copied. The cloning process is inefficient: only around 3\% of cell nuclei that are transferred to donor eggs result in live births. But no large-scale followups of those births have been done, so little is known about whether clones really are likely to die young.

The health of adult clones has been studied most extensively in mice. At least 200 live mouse clones have been created in $\mathbf{1 0}$ or so labs around the world. In one study, Narumi Ogonuki of the National Institute of Infectious Diseases in Tokyo tracked the health of 12 mouse clones and found that 10 died - probably of pneumonia or liver disease - before their average natural lifespan of $\mathbf{8 0 0}$ days (N. Ogonuki et al. Nature Genet. 30, 253-254; 2002). But other researchers say that problems seen at birth or shortly afterwards, such as obesity, can reverse as the animals age. The offspring of other cloned mice have also been reported to be normal (K. L. K. Tamashiro et al. Nature Med. 8, 262-267; 2002).

Researchers say that experiments with larger numbers of animals are needed, but are difficult to carry out given the

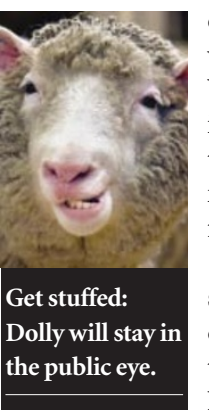
difficulties associated with creating clones. Work on some animals is hampered by a lack of time and money. "You need to follow them for life. We're talking 15-plus years for cows," says Keith Campbell, a cloning researcher at the University of Nottingham, UK.

\title{
Poor farmers warned against Intemet transgenic crop deals
}

Rex Dalton

From a farmhouse in Northern Ireland, a married couple is using the Internet to tempt farmers in developing nations into planting crops that are genetically engineered to produce commercially useful molecules.

Environmentalists and scientists have expressed concern at the couple's attempts to get poor farmers from Asia to Africa to agree to make thousands of hectares available to biotechnology companies.

Critics of the plan say that it could cause an ecological disaster if local plants or crops became contaminated with transgenic strains, as developing countries often have no governmental resources for monitoring the spread of transgenes. They fear that farmers could be held responsible in the event of any such outbreak.

Brian and Diane Marshall, who live on an 80-hectare farm in Newtowncunningham near Londonderry, have used suggestions of huge monetary returns to encourage farmers from around the world to sign up to their year-old website, www.molecularfarming.com. They hope to broker contracts between the farmers and biotech firms seeking new regions to grow biopharmaceutical crops such as genetically engineered maize and tobacco. They are also seeking land in developed nations, but environmentalists are less concerned about countries that already have strict regulations for monitoring transgenic organisms.

The couple, who are also seeking to collaborate with universities, insist that they have no financial arrangement with any major pharmaceutical or agricultural firm.

The Edmonds Institute, an environmental organization based near Seattle, Washington, issued an alert about the enterprise last week. "I'm concerned about the ecosystems where these crops may be introduced," says Beth Burrows, the institute's director. She fears that "small farmers in outof-the-way places" will be held responsible if something goes wrong.

Brian Marshall retorts that the crops will not be grown for food and that potential biopharmaceutical crops will be selected to minimize the possibility of ecological damage.

But some academic scientists who are engaged in research on pharmaceutical crops are steering clear of Marshall's enterprise, fearing that the initiative could damage their research and development efforts.

"We wouldn't do anything with him," says Charles Arntzen, a plant geneticist at Arizona State University in Tempe with whom Mar-

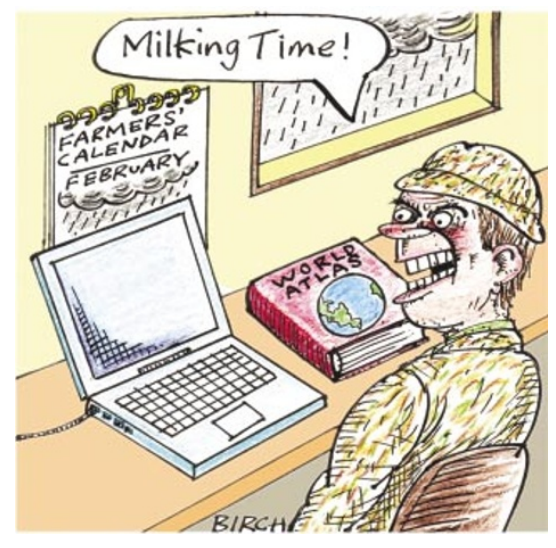

shall had attempted to forge a collaboration. Arntzen's research involves genetically engineering plants to produce human vaccines. "This is dangerous stuff to poor people in poor countries. And it would be political death for getting research money in the future," Arntzen says.

Marshall also sought out the biotech company ProdiGene, based in College Station, Texas, as a potential collaborator. ProdiGene was fined US $\$ 250,000$ by the US Department of Agriculture (USDA) last December after its biopharmaceutical maize in Nebraska and Iowa contaminated other field crops. Anthony Laos, ProdiGene's chief executive, says that the company is not currently collaborating with Marshall, but adds: "That's not to say we wouldn't in the future."

Environmentalists in developing nations are shocked by the Marshalls' plan. Devinder Sharma, a plant geneticist and chair of the Forum for Biotechnology and Food Security in New Delhi, India, calls it "part of the global design to translocate dirty industry to the Third World".

"We cannot allow this," Sharma continues. "Let us not put the poor farmer in another trap that will land him in serious trouble."

Brian Marshall has no formal scientific training; Diane Marshall is a business professor at the North West Institute of Further and Higher Education in Londonderry. They launched their venture after changes to European regulations reduced their income from their sheep and cattle farm.

"We are full-time farmers fed up with being squeezed out of traditional farming income," Brian says. But Norman Ellstrand, a plant geneticist at the University of California, Riverside, sees the Marshalls' plan as "a frightening possibility" for the developing world's farmers. 